\title{
Simultaneous surface-adsorbed organic matter desorption and cell integrity maintenance by moderate prechlorination to enhance Microcystis aeruginosa removal in $\mathrm{KMnO}_{4}-\mathrm{Fe}(\mathrm{II})$ process
}

\author{
Jing Qi ${ }^{\text {a, c }}$, Huachun Lan ${ }^{\text {b, * }}$, Huijuan Liu ${ }^{\text {a, c }}$, Ruiping Liu ${ }^{\text {b, c }}$, Shiyu Miao a , Jiuhui Qu ${ }^{\text {b, c }}$ \\ a State Key Laboratory of Environmental Aquatic Chemistry, Research Center for Eco-Environmental Sciences, Chinese Academy of Sciences, Beijing 100085, \\ China \\ b Key Laboratory of Drinking Water Science and Technology, Research Center for Eco-Environmental Sciences, Chinese Academy of Sciences, Beijing 100085 , \\ China \\ ${ }^{\mathrm{c}}$ University of Chinese Academy of Sciences, Beijing 100049, China
}

\section{A R T I C L E I N F}

\section{Article history:}

Received 28 July 2016

Received in revised form

20 September 2016

Accepted 21 September 2016

Available online 21 September 2016

\section{Keywords:}

$\mathrm{KMnO}_{4}-\mathrm{Fe}$ (II) process

Microcystis aeruginosa removal

Moderate prechlorination

Surface-adsorbed organic matter

Cell integrity

\begin{abstract}
A B S T R A C T
The $\mathrm{KMnO}_{4}-\mathrm{Fe}(\mathrm{II})$ process was proved to have good application potential in Microcystis aeruginosa removal, although at relatively high doses. This study aims to improve the algae removal in $\mathrm{KMnO}_{4}-\mathrm{Fe}(\mathrm{II})$ process by moderate prechlorination, which can realize the desorption of surfaceadsorbed organic matter (S-AOM) from algae cells without damaging cell integrity. S-AOM was proved to not only inhibit algae removal but also maintain cell integrity, using various dilution methods for algal suspension preparation. The dilution after filtration method mainly removed the dissolved organics in cultured M. aeruginosa, while the dilution after centrifugal cleaning method could also remove the SAOM on algae cells. Compared with the S-AOM-removed algal suspension, the lower algae removal in $\mathrm{KMnO}_{4}-\mathrm{Fe}(\mathrm{II})$ process and the reduced proportion of damaged cells during prechlorination of algal suspension without S-AOM removed indicated the inhibitory role of S-AOM in algae removal and the protective function of S-AOM toward cell integrity, respectively. Moderate prechlorination of directly diluted M. aeruginosa could be realized at chlorine doses of below $0.5 \mathrm{mg} / \mathrm{L}$, and the damaged cell ratios were below $4 \%$ after 5 -min prechlorination. The ability of the $\mathrm{KMnO}_{4}-\mathrm{Fe}(\mathrm{II})$ process to remove algae was dramatically enhanced by the elevation of chlorine dose from 0 to $0.5 \mathrm{mg} / \mathrm{L}$, as more S-AOM was desorbed during prechlorination. Additionally, algae cells were easily captured by flocs after moderate prechlorination, which benefited the floc aggregation for formation of tightly bounded algae flocs. Therefore, the desorption of S-AOM without damaging cell integrity is the key feature of moderate prechlorination, which can be applied in improving the algae removal of $\mathrm{KMnO}_{4}-\mathrm{Fe}(\mathrm{II})$ process.
\end{abstract}

() 2016 Published by Elsevier Ltd.

\section{Introduction}

The removal of algae cells in water sources is a continuing concern for drinking water treatment plants (DWTPs) worldwide. The traditional water treatment processes show limited efficiency in achieving satisfactory removal of algae cells, not only because of the high motility, low specific density, diverse morphology and negative surface charge characteristics of algae cells (Pieterse and Cloot, 1997), but also due to the existence of algal organic matter (AOM) (Pivokonsky et al., 2006). The surface-adsorbed organic

\footnotetext{
* Corresponding author.

E-mail address: hclan@rcees.ac.cn (H. Lan).
}

matter (S-AOM) was reported to stabilize the algae cells in water, which increases the difficulty of removing algae cells for DWTPs (Clasen et al., 2000; Takaara et al., 2010). S-AOM refers to all the organic matter adsorbed on algae cells, including both the extracellular organic matter (EOM) and natural organic matter (NOM). The thickness of S-AOM could be reached to more than $20 \mu \mathrm{m}$ when the algae cells form colonies of different sizes with mucilage or sheaths under natural conditions (Reynolds, 2007; Wu et al., 2007; Fan et al., 2016).

Many strategies have been proposed to enhance algae removal based on the conventional treatment processes, such as the introduction of dissolved air flotation, ultrafiltration, hydrodynamic cavitation and electro-coagulation-flotation processes (Henderson et al., 2008; Gao et al., 2010; Yang and Chen, 2013; Li et al., 2014). 
However, these strategies are all hindered by the high investment required for facilities modification. The $\mathrm{KMnO}_{4}-\mathrm{Fe}(\mathrm{II})$ process was proposed in our former study to achieve enhanced algae removal without large-scale reconstruction (Ma et al., 2012a). The process was further optimized successively to achieve maximum algae removal and minimum residual $\mathrm{Mn}$ for the same $\mathrm{Fe}(\mathrm{II})$ dose, and the optimum molar ratio of $\mathrm{KMnO}_{4}$ to $\mathrm{Fe}(\mathrm{II})$ [RKMnO 4 : $\left.\mathrm{Fe}(\mathrm{II})\right]$ was found to be 1: 3 (Qi et al., 2016a). The in-situ formed Fe(III) in the $\mathrm{KMnO}_{4}-\mathrm{Fe}$ (II) process was proved to be more efficient for algae removal than pre-formed $\mathrm{Fe}(\mathrm{III})$, because of its large reactive surface area (Ma et al., 2012a). In addition, the in-situ $\mathrm{MnO}_{2}$ formed from the reduction of $\mathrm{KMnO}_{4}$ can also serve as nuclei to promote coagulation and contribute to floc growth and sedimentation (Chen and Yeh, 2005; Sun et al., 2009; Qi et al., 2016a). However, the algae removal efficiency is highly dependent on the doses of $\mathrm{KMnO}_{4}$ and $\mathrm{Fe}(\mathrm{II})$ (Qi et al., 2016a), which need to be reduced.

It is worth mentioning that the reaction between $\mathrm{KMnO}_{4}$ and $\mathrm{S}$ AOM has been reported to play an important role in enhancing algae removal for coagulation by destabilizing the algae cells (Xie et al., 2013; Qi et al., 2016a). The oxidation function of $\mathrm{KMnO}_{4}$ to desorb the S-AOM on algae cells is weaker than for other oxidants, such as ozone and chlorine (Fan et al., 2013, 2014). This means that S-AOM desorption from algae cells can be enhanced by the introduction of more effective oxidants before the $\mathrm{KMnO}_{4}-\mathrm{Fe}(\mathrm{II})$ process. Chlorine, as the most widely used oxidant around the world, has been proposed for algae-laden raw water preoxidation (Shen et al., 2011). However, over-dosed chlorine pretreatment has been reported to damage cell integrity and induce intracellular organic matter (IOM) release (Daly et al., 2007; Lin et al., 2009; Ma et al., 2012b), which will not only inhibit coagulation but also increase disinfection by-products (DBPs) formation during disinfection (Garzon-Sanabria et al., 2013; Zhou et al., 2015; Zhu et al., 2015). Therefore, an ideal prechlorination step before the $\mathrm{KMnO}_{4}-\mathrm{Fe}(\mathrm{II})$ process should be "moderate" to achieve not only the desorption of S-AOM but also the maintenance of cell integrity simultaneously.

In addition, lower-dosed oxidant has been reported to mainly react with the S-AOM without damaging the algae cell integrity (Xie et al., 2013; Qi et al., 2016a, 2016b). Thus, S-AOM can be conjectured to benefit the cell integrity maintenance during oxidation, and this effect can avoid the IOM release induced by cell damage to a certain extent. Therefore, the role of S-AOM needs to be assessed not only regarding its algae removal inhibitory effect, but also from the cell integrity protective aspect. However, no studies have been performed to directly prove the two roles of S-AOM, which is a fundamental guide for moderate prechlorination. Consequently, it is important to realize moderate prechlorination according to the two roles of S-AOM before applying prechlorination in the $\mathrm{KMnO}_{4}-\mathrm{Fe}(\mathrm{II})$ process.

Based on the above considerations, this study aims to: 1) investigate the inhibitory role of S-AOM in algae removal; 2) verify the protective function of S-AOM toward cell integrity; 3 ) clarify the moderate prechlorination process from both S-AOM desorption and cell integrity maintenance aspects; 4 ) evaluate the feasibility of applying moderate prechlorination in algae removal by the $\mathrm{KMnO}_{4}-\mathrm{Fe}(\mathrm{II})$ process.

\section{Materials and methods}

\subsection{Materials and reagents}

The algae species used in this study was Microcystis aeruginosa because of its prevalence in algae blooms and relevance to water quality and treatment challenges in waterworks (Kemp and John, 2006; Sano et al., 2011). M. aeruginosa (strain FACHB-905), as a cyanobacterium, previously described by Shen et al. (Shen and Song, 2007), was obtained from Wuhan Institute of Hydrobiology,

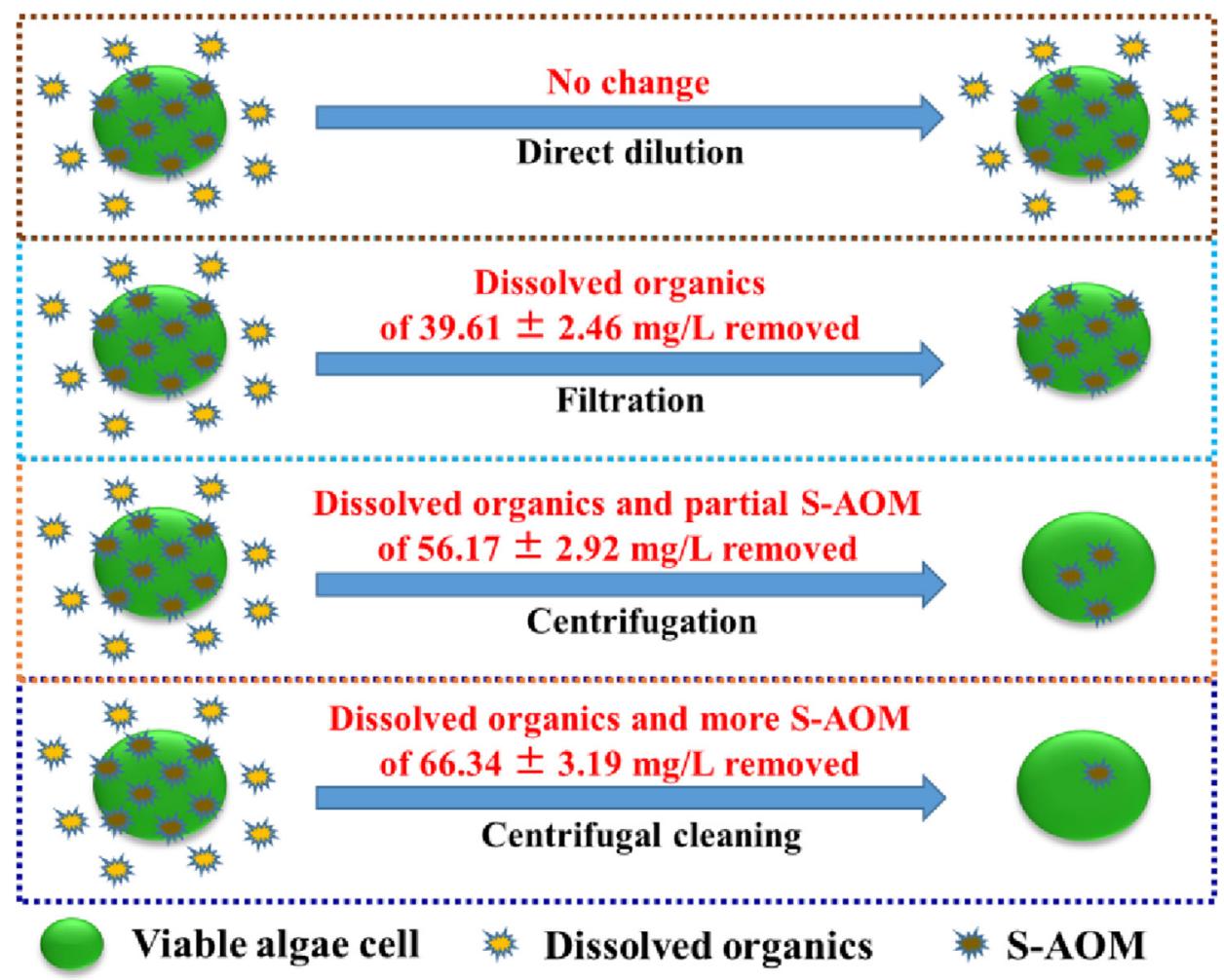

Fig. 1. Diagram of dilution method effects on the removal of dissolved organics and S-AOM from cultured M. aeruginosa. 
Chinese Academy of Sciences, and cultured in BG-11 medium (Rippka et al., 1979). The detailed algae growth conditions are presented in Text S1. M. aeruginosa cultures were harvested at the exponential growth phase and diluted to the cell density of $1.0 \times 10^{6}$ cells $/ \mathrm{mL}$ for all experiments. SYTOX green nucleic acid stain was purchased from Invitrogen, USA. Sodium hypochlorite (NaOCl, Sigma-Aldrich) stock solution, phosphate buffer solution (PBS; $10 \mathrm{mM}, \mathrm{pH}=7.5$ ) and ferrous sulfate $\left(\mathrm{FeSO}_{4} \cdot 7 \mathrm{H}_{2} \mathrm{O}\right)$ solution were prepared just before experiments with Milli-Q water. Potassium permanganate $\left(\mathrm{KMnO}_{4}\right)$ and sodium thiosulfate $\left(\mathrm{Na}_{2} \mathrm{~S}_{2} \mathrm{O}_{3}\right)$ stock solutions of $0.5 \mathrm{~g} / \mathrm{L}$ were prepared every week and stored in darkness. Source water was collected from the Qingcaosha reservoir located in Shanghai, China. The basic qualities of the source water were as follows: turbidity 3.8 NTU, pH 7.7, DOC $3.26 \mathrm{mg} / \mathrm{L}$.

\subsection{Experimental methods}

Four dilution methods with source water were used for testing the inhibitory role of S-AOM in algae removal by the $\mathrm{KMnO}_{4}-\mathrm{Fe}(\mathrm{II})$ process, including direct dilution and dilution of the deposited algae cells after filtration (GF/F membrane, Whatman), centrifugation (4500 rpm, 10 min; supernatant removal), and centrifugal cleaning (4500 rpm, $10 \mathrm{~min}$; three cycles of centrifugation and supernatant removal) respectively. The $\mathrm{pH}$ of this algal suspension was about 7.9. All jar tests were performed with $300 \mathrm{~mL}$ samples in $500 \mathrm{~mL}$ beakers and conducted on a programmable jar tester (MY3000-6, MeiYu, China). All samples were rapidly mixed with the added $\mathrm{KMnO}_{4}$ at $250 \mathrm{rpm}$ for 5 min before the addition of $\mathrm{Fe}(\mathrm{II})$. The subsequent process consisted of mixing at $200 \mathrm{rpm}$ for $2 \mathrm{~min}$ and $40 \mathrm{rpm}$ for $15 \mathrm{~min}$, consecutively. Then, samples were quiescently settled for $30 \mathrm{~min}$. After settling, samples were siphoned $2 \mathrm{~cm}$ below the water surface, and measured for residual algae by optical density at $680 \mathrm{~nm}\left(\mathrm{OD}_{680}\right)$.

In order to test the protective function of S-AOM toward cell integrity, the cultured algae cells were suspended with PBS after filtration and centrifugal cleaning respectively. All samples were rapidly mixed at $250 \mathrm{rpm}$ for $5 \mathrm{~min}$ after the addition of chlorine $(0$, $0.2,0.4,0.8 \mathrm{mg} / \mathrm{L}) . \mathrm{Na}_{2} \mathrm{~S}_{2} \mathrm{O}_{3}$ was then added to quench the prechlorination, and samples were siphoned for cell integrity detection.

The effects of prechlorination on cell integrity and S-AOM desorption were tested by the direct dilution of algae cells with source water. All the samples were rapidly mixed with the added chlorine $(0-2 \mathrm{mg} / \mathrm{L})$ at $250 \mathrm{rpm}$ for $5 \mathrm{~min} \mathrm{Na}_{2} \mathrm{~S}_{2} \mathrm{O}_{3}$ was then added to quench the prechlorination. Samples were siphoned and divided in two subsamples: the first sample was evaluated for cell integrity detection. The remaining sample was immediately filtered through a $0.45 \mu \mathrm{m}$ glass fiber filter for the concentration determination of DOC.

For testing the effects of prechlorination on algae removal by the $\mathrm{KMnO}_{4}-\mathrm{Fe}(\mathrm{II})$ process, samples were rapidly mixed with the added chlorine $(0-2 \mathrm{mg} / \mathrm{L})$ at $250 \mathrm{rpm}$ for $5 \mathrm{~min}$ before the $\mathrm{KMnO}_{4}-\mathrm{Fe}(\mathrm{II})$ process. The $\mathrm{KMnO}_{4}-\mathrm{Fe}(\mathrm{II})$ process was conducted according to the former procedure described for jar tests. After settling, samples were siphoned and measured for residual algae by $\mathrm{OD}_{680}$ and algae flocs observation.

\subsection{Analytical methods}

\subsubsection{Cell integrity detection}

Cell integrity was determined for individual cells using a flow cytometer (FACSCalibur 4CLR, BD Biosciences, San Jose, USA) equipped with an argon ion laser emitting at a fixed wavelength of $488 \mathrm{~nm}$ for fluorescence measurement. SYTOX green nucleic acid stain was used to determine the cell integrity according to the method of Daly (Daly et al., 2007). Full details of the cell integrity analysis are presented in Text S2.

\subsection{2. $O D_{680}$ of algal suspension}

$\mathrm{OD}_{680}$ of the algal suspension was measured with a U-3100 spectrophotometer (Hitachi Co., Japan). The path length of the quartz cell was $10 \mathrm{~mm}$. Milli-Q water served as the control.

\subsubsection{Analysis of $D O C$}

The DOC concentration in the dissolved phase of algal suspension was measured with a Shimadzu TOC- $\mathrm{V}_{\mathrm{CPH}}$ analyzer.

\subsubsection{Algae flocs observation}

Scanning electron microscopy (SEM; SU-8020, Hitachi, Japan) was used to observe the morphologies of algae flocs formed during the $\mathrm{KMnO}_{4}-\mathrm{Fe}(\mathrm{II})$ process after prechlorination.

\section{Results and discussion}

\subsection{The inhibitory role of $S-A O M$ in algae removal by the $\mathrm{KMnO}_{4}-\mathrm{Fe}(\mathrm{II})$ process}

To investigate the role of S-AOM in algae removal and cell integrity, four dilution methods were used for algal suspension preparation, including direct dilution and diluting the deposited
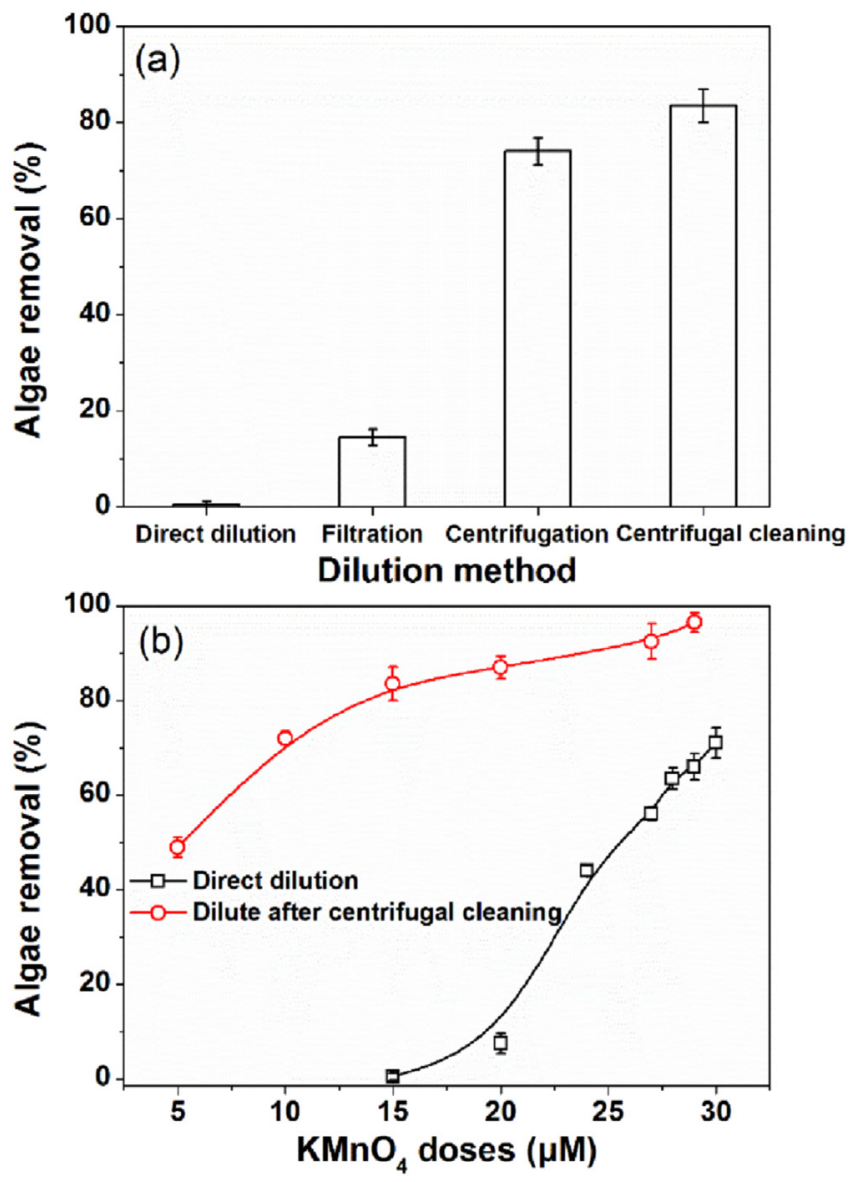

Fig. 2. Effects of differences in dissolved organics and S-AOM induced by different dilution methods on algae removal by the $\mathrm{KMnO}_{4}-\mathrm{Fe}(\mathrm{II})$ process. Cell density of $1.0 \times 10^{6}$ cells $/ \mathrm{mL}$ was obtained with source water. (a) $\mathrm{KMnO}_{4}$ dose $=15 \mu \mathrm{M} ; \mathrm{Fe}$ (II) dose $=45 \mu \mathrm{M}$. (b) $\mathrm{RKMnO}_{4}: \mathrm{Fe}(\mathrm{II})=1$ : 3 . The results shown are mean data from triplicate experiments, and error bars indicate standard deviations based on triplicate analyses. 
cells after filtration, centrifugation, and centrifugal cleaning respectively. The effects of dilution methods on the removal of dissolved organics and S-AOM from cultured algae are summarized in Fig. 1.

The directly diluted algal suspension contains both organics in the dissolved phase and S-AOM on algae cells. The filtration method can mainly remove the dissolved organics in cultured algae. Centrifugation has been widely used for separating the algae cells from the cultured suspension (Henderson et al., 2010; Takaara et al., 2010; Xie et al., 2013). The DOC concentration in the solution of cultured $M$. aeruginosa after centrifugal cleaning was $66.34 \pm 3.19 \mathrm{mg} / \mathrm{L}$, while only $39.61 \pm 2.46 \mathrm{mg} / \mathrm{L}$ for the sample obtained after filtration. This result indicates that the dilution methods after centrifugation, especially after centrifugal cleaning, can remove not only the dissolved organics in cultured M. aeruginosa but also S-AOM on algae cells.

The effects of S-AOM on algae removal from source water are illustrated in Fig. 2a; the fixed doses of $\mathrm{KMnO}_{4}$ and $\mathrm{Fe}(\mathrm{II})$ were 15 and $45 \mu \mathrm{M}$, respectively. The algae removal efficiency was $0.5 \%$ by the $\mathrm{KMnO}_{4}-\mathrm{Fe}(\mathrm{II})$ process for the directly diluted algal suspension, which contained not only dissolved organics but also S-AOM. A slight increase of $14 \%$ was obtained for the filtered algal suspension with the dissolved organics removed. Further enhancement of algae removal efficiency was achieved by the dilution method after centrifugation and centrifugal cleaning, with increases to $74 \%$ and 83.5\% respectively. The highest algae removal efficiency was obtained when the most S-AOM was removed, in the centrifugal cleaning algal suspension. This result can directly prove that the SAOM played a more serious inhibitory role in algae removal than the dissolved organics. AOM has been proved to be an inhibitory substance for coagulation (Bernhardt et al., 1989). S-AOM can stabilize the algae cells and enhance the difficulty of removing algae cells by coagulation (Clasen et al., 2000; Takaara et al., 2010). One of the proposed mechanisms for the inhibitory function is the direct interaction of AOM with cations originating from the coagulant to form complexes, impeding the coagulation capability (Bernhardt et al., 1989), which can explain the role of S-AOM in stabilizing algae cells.

In order to further demonstrate the inhibitory role of S-AOM in algae removal from source water, the algae removal efficiency was tested with various doses of $\mathrm{KMnO}_{4}$ and $\mathrm{Fe}(\mathrm{II})$ for the direct dilution and centrifugal cleaning dilution methods (Fig. 2b). The enhancement of algae removal after the centrifugal cleaning dilution method was remarkable, especially for low $\mathrm{KMnO}_{4}$ doses of less than $20 \mu \mathrm{M}$. The $\mathrm{KMnO}_{4}-\mathrm{Fe}(\mathrm{II})$ process at $\mathrm{RKMnO}_{4}$ : $\mathrm{Fe}(\mathrm{II})$ of $1: 3$ was proved to have good performance in algae removal, and the removal efficiency increased with elevated doses of $\mathrm{KMnO}_{4}$ and $\mathrm{Fe}(\mathrm{II})$ (Qi et al., 2016a). $\mathrm{KMnO}_{4}$ was reported to mainly react with the dissolved organics and S-AOM on algae cells prior to $\mathrm{Fe}(\mathrm{II})$ addition (Xie et al., 2013; Qi et al., 2016a). The directly diluted algal suspension contains more S-AOM on algae cells, and needs a higher dose of $\mathrm{KMnO}_{4}$ for oxidation. These results indicate that S-AOM can serve as a protective barrier stabilizing algae cells and inhibiting the algae removal.

\subsection{The protective function of S-AOM toward algae cell integrity during prechlorination}

Fig. 3 shows the effects of S-AOM on algae cell integrity, and the ratios of damaged algae cells were quantified by a flow cytometer. The algal suspension was prepared in PBS in order to exclude the influence of organics in the water body, and the maintenance of cell integrity in PBS has been proved by previous research (Wert et al., 2013; Qi et al., 2016a). The fluorescence were collected in channel FL1 $(530 \mathrm{~nm})$ and FL3 $(630 \mathrm{~nm})$ respectively to identify the algae cell integrity. The red dots in the upper area for each sample refer to
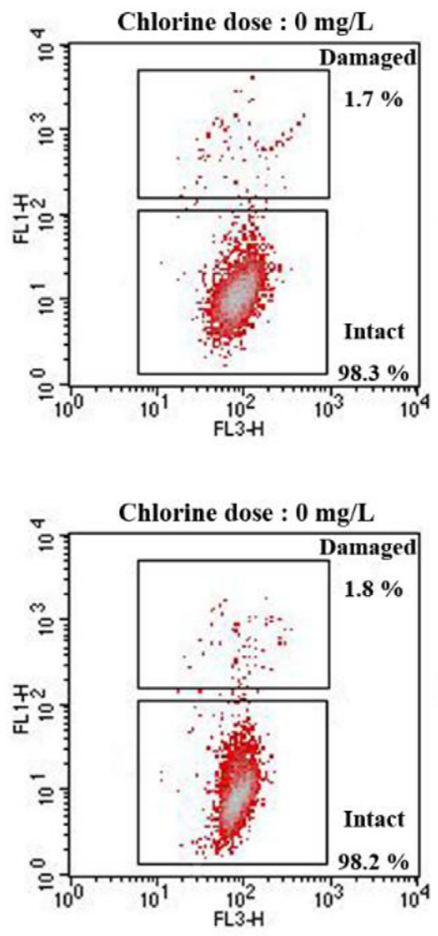
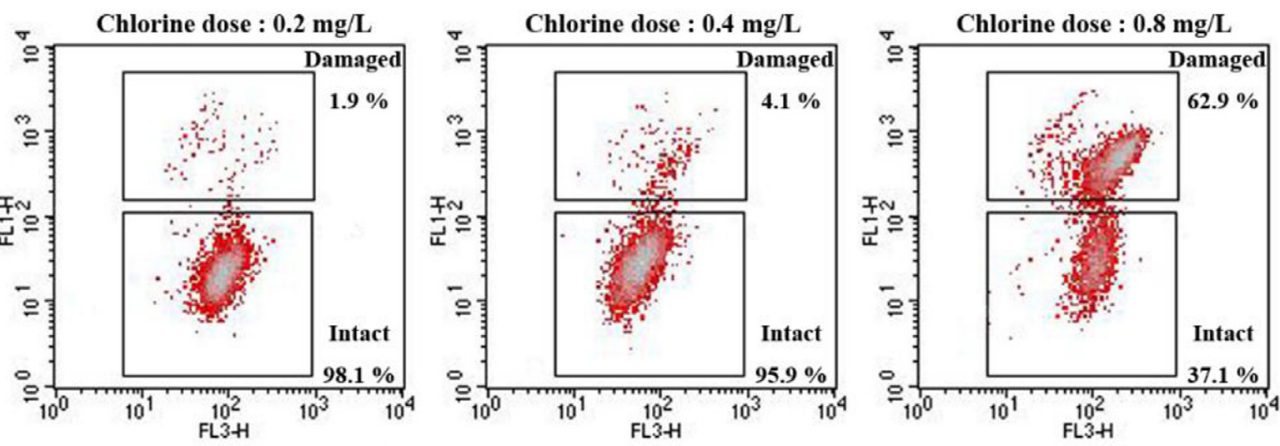

(a) Dilution after filtration
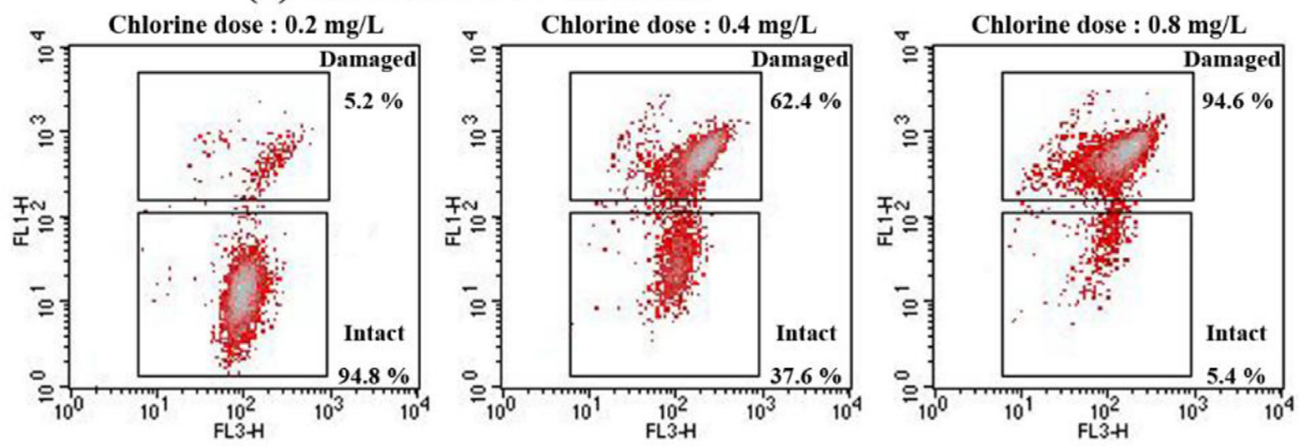

(b) Dilution after centrifugal cleaning

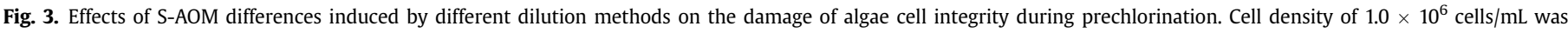
obtained with PBS. Prechlorination time: 5 min. FL1: 530 nm, FL3: $630 \mathrm{~nm}$. 
those algae cells which have lost cell integrity. It can be observed that the ratios of damaged cells increased with the elevation of chlorine dose for both of the dilution methods. In addition, the damaged cell ratios for the dilution after centrifugal cleaning method were all higher than the ratios after filtration, with the same chlorine dosage for preoxidation. When the chlorine dose was $0.4 \mathrm{mg} / \mathrm{L}$, the ratio of damaged cells rose from $4.1 \%$ for the filtered algal suspension to $62.4 \%$ for the centrifugal cleaning suspension. The chlorine dose should be increased to $0.8 \mathrm{mg} / \mathrm{L}$ to obtain a similar damaged cells ratio, i.e., $62.9 \%$, for the filtered algal suspension.

Chlorine has been reported to be capable of damaging algae cells, and the damage level is highly dependent on the oxidant dose (Wert et al., 2013; Fan et al., 2014). Chlorine at low dose, i.e., $0.2 \mathrm{mg} /$ $\mathrm{L}$, mainly reacted with the S-AOM rather than damaging the algae cells during the 5-min preoxidation for the filtered algal suspension, as indicated by the low ratios of damaged cells in Fig. 3a. The algae cells diluted after centrifugal cleaning were more easily damaged by prechlorination compared with the cells after filtration. These results indicate that S-AOM might play a protective role for algae cells during the prechlorination period. Similar results have been reported that oxidant at lower doses mainly reacts with the S-AOM without damaging the algae cell integrity (Xie et al.,
2013; Qi et al., 2016a, 2016b).

\subsection{Effects of prechlorination on algae cell integrity and S-AOM desorption}

Fig. 4 shows the effect of prechlorination on the cell integrity of directly diluted $M$. aeruginosa in source water, with chlorine doses from 0 to $2 \mathrm{mg} / \mathrm{L}$. The ratios of damaged algae cells increased with the elevation of chlorine dose. Chlorine at doses below $0.5 \mathrm{mg} / \mathrm{L}$ showed little effect on cell integrity, and the ratios of damaged cells were below $4 \%$ after 5 -min preoxidation. However, the ratios of damaged algae cells increased from $3.3 \%$ to $18.2 \%$ with the elevation of chlorine dose from $0.5 \mathrm{mg} / \mathrm{L}$ to $0.6 \mathrm{mg} / \mathrm{L}$. When the chlorine dose was elevated to $2 \mathrm{mg} / \mathrm{L}$, almost all the algae cells were damaged after prechlorination.

Chlorine at low doses, i.e., below $0.5 \mathrm{mg} / \mathrm{L}$, mainly reacted with the dissolved organics and S-AOM rather than directly damaging the algae cells during the 5 -min preoxidation, as indicated by the low ratios of damaged cells. This result is in agreement with the previous findings that chlorine is capable of damaging algae cells, and the damage extent is mainly influenced by the oxidant dose (Wert et al., 2013; Fan et al., 2014). The protective function of SAOM on cell integrity has also been proved as shown in Fig. 3,

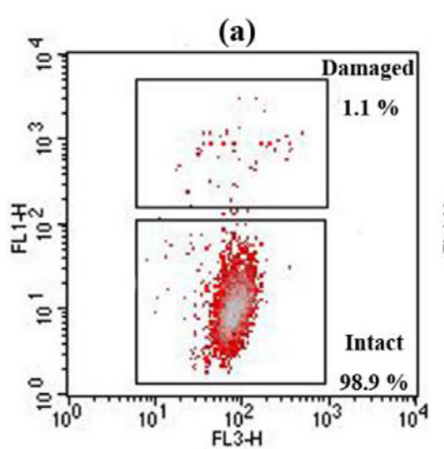

(e)

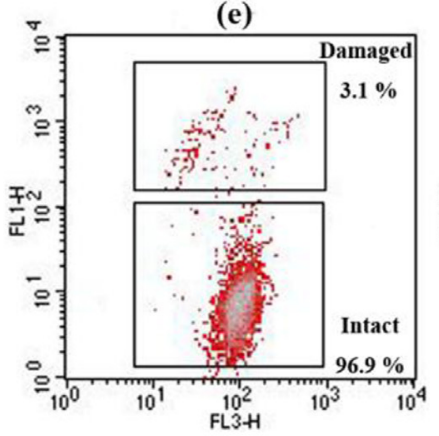

(i)

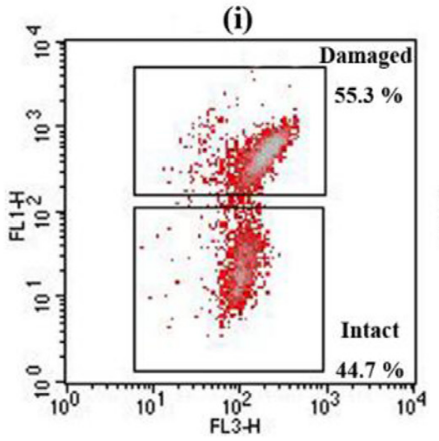

(b)

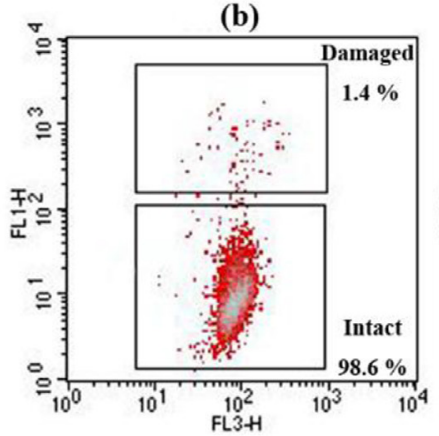

(f)

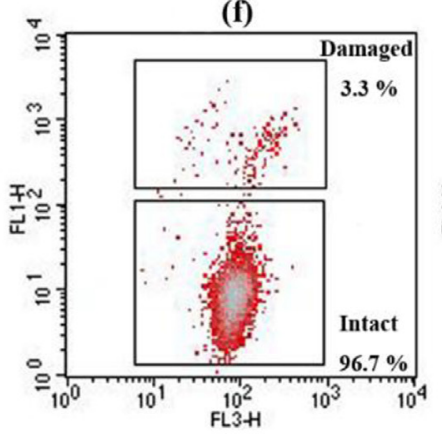

(j)

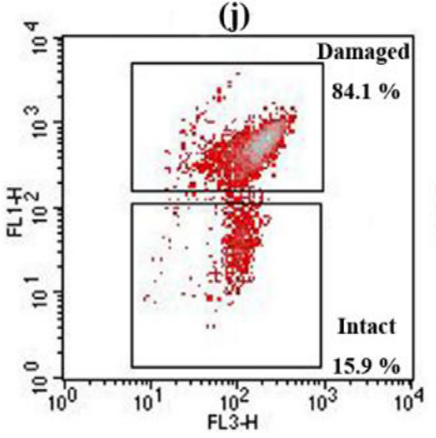

(c)

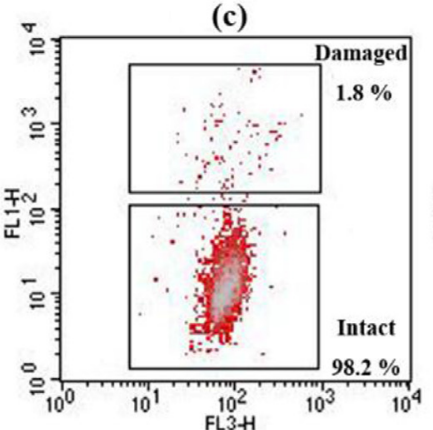

(g)

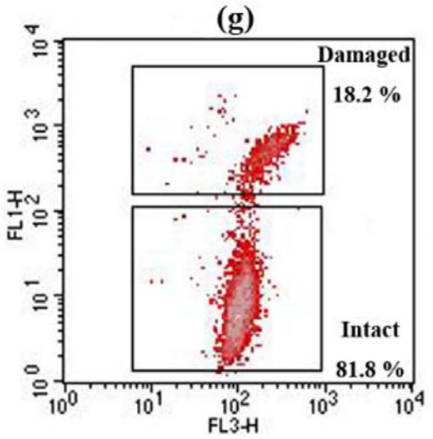

(k)

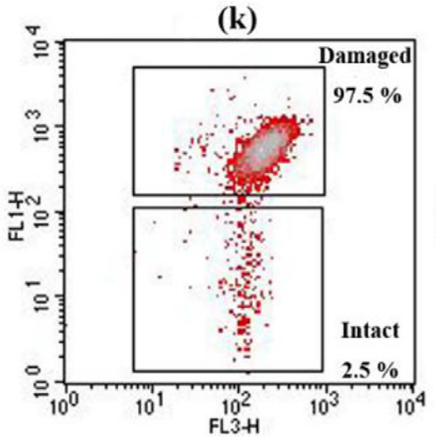

(d)

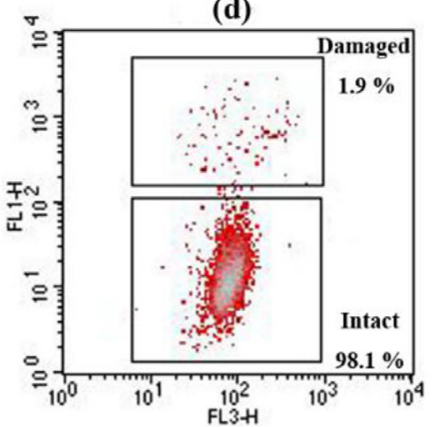

(h)

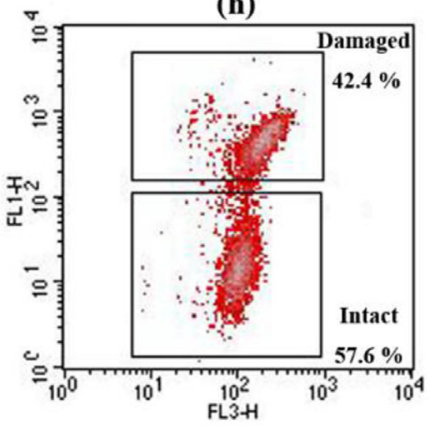

(I)

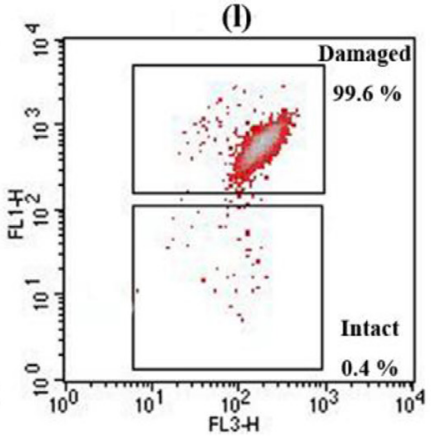

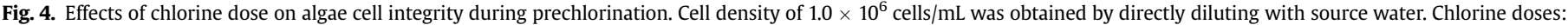

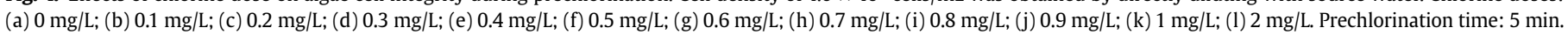
FL1: 530 nm, FL3: 630 nm. 
Table 1

Effects of chlorine doses on DOC in algal suspension after prechlorination. ${ }^{a}$

\begin{tabular}{|c|c|c|c|c|c|c|c|c|c|c|c|c|}
\hline Chlorine doses (mg/L) & 0 & 0.1 & 0.2 & 0.3 & 0.4 & 0.5 & 0.6 & 0.7 & 0.8 & 0.9 & 1 & 2 \\
\hline $\mathrm{DOC}(\mathrm{mg} / \mathrm{L})$ & 4.27 & 4.35 & 4.41 & 4.52 & 4.63 & 4.74 & 4.95 & 5.03 & 5.16 & 5.36 & 5.51 & 5.62 \\
\hline
\end{tabular}

${ }^{\text {a }}$ Cell density of $1.0 \times 10^{6}$ cells $/ \mathrm{mL}$ was obtained by directly diluting with source water. The results shown are mean data from triplicate experiments.

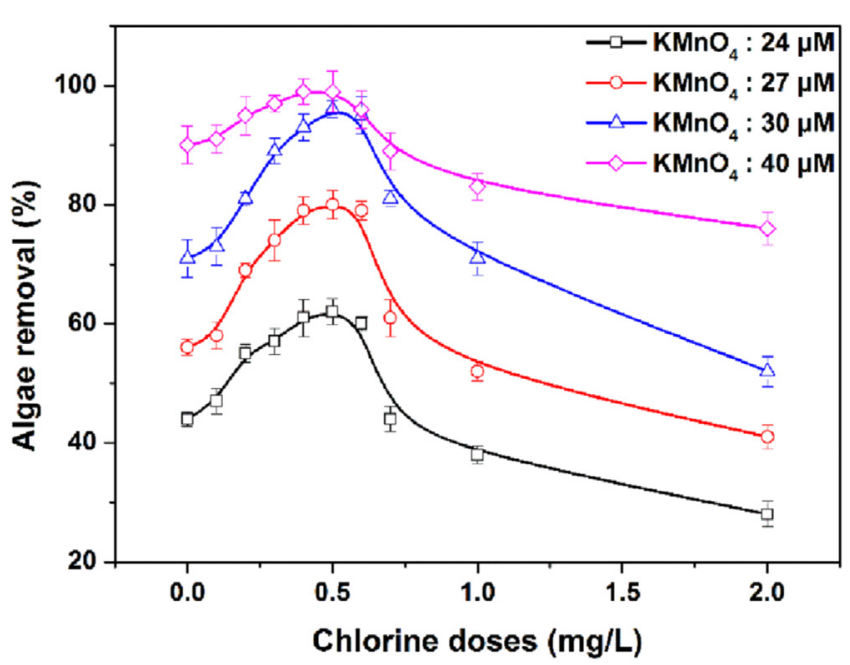

Fig. 5. Effects of chlorine dose on algae removal by the $\mathrm{KMnO}_{4}-\mathrm{Fe}(\mathrm{II})$ process. Cell density of $1.0 \times 10^{6}$ cells $/ \mathrm{mL}$ was obtained by directly diluting with source water. $\mathrm{RKMnO}_{4}: \mathrm{Fe}(\mathrm{II})=1: 3$. The results shown are mean data from triplicate experiments, and error bars indicate standard deviations based on triplicate analyses.

which can explain the low ratios of damaged cells. However, an elevated chlorine dose, i.e., above $0.6 \mathrm{mg} / \mathrm{L}$, could induce high ratios of cell damage due to the loss of protective S-AOM.

The variation of DOC values after the prechlorination of directly diluted M. aeruginosa is shown in Table 1 . The elevation of chlorine dose from 0 to $2 \mathrm{mg} / \mathrm{L}$ increased the DOC value from 4.27 to $5.62 \mathrm{mg} / \mathrm{L}$. The DOC value increased, i.e., $0.47 \mathrm{mg} / \mathrm{L}$, after the 5-min preoxidation by $0.5 \mathrm{mg} / \mathrm{L}$ chlorine, even though the ratio of damaged cells induced was below $4 \%$. Combined with the low damaged cell integrity result, it can be inferred that the DOC increase after lower dose chlorine (i.e., below $0.5 \mathrm{mg} / \mathrm{L}$ ) preoxidation is mainly caused by the desorbed S-AOM rather than released IOM. In addition, the further increased DOC values at higher chlorine doses, i.e., above $0.6 \mathrm{mg} / \mathrm{L}$, were induced by the released IOM from damaged cells, which has been reported to adversely influence waterworks to a large degree (Garzon-Sanabria et al., 2013; Feng et al., 2014). Therefore, the algae cell lysis problem can be prevented with moderate prechlorination, which can avoid not only the demand of extra chlorine to oxidize released toxins (Daly et al., 2007) but also the formation of DBPs at problematic level (Qi et al., 2016b). Considering that the effect of prechlorination on algae cells is strongly dependent on cell density and water matrix, the influence of chlorine dose in algae cell integrity and S-AOM desorption should be further verified in the actual water bodies to achieve the appropriate chlorine range.

\subsection{Effects of prechlorination on algae removal by $\mathrm{KMnO}_{4}-\mathrm{Fe}(\mathrm{II})$ process}

To illustrate the effects of prechlorination on the removal of directly diluted $M$. aeruginosa in source water by the $\mathrm{KMnO}_{4}-\mathrm{Fe}(\mathrm{II})$ process, chlorine at doses from 0 to $2 \mathrm{mg} / \mathrm{L}$ was added, and the $\mathrm{KMnO}_{4}$ doses were $24,27,30$, and $40 \mu \mathrm{M}$, respectively (Fig. 5). The removal of algae by $\mathrm{KMnO}_{4}-\mathrm{Fe}(\mathrm{II})$ process increased with increasing chlorine dose up to $0.5 \mathrm{mg} / \mathrm{L}$ but decreased at higher concentrations at all the fixed $\mathrm{KMnO}_{4}$ doses. When the $\mathrm{KMnO}_{4}$ dose was $30 \mu \mathrm{M}$, the algae removal was increased from $71 \%$ to $96 \%$ with the elevation of chlorine dose from 0 to $0.5 \mathrm{mg} / \mathrm{L}$. However, further elevation of chlorine dose from 0.6 to $2 \mathrm{mg} / \mathrm{L}$ decreased the algae removal efficiency. The lowest algae removal was obtained with $2 \mathrm{mg} / \mathrm{L}$ chlorine pretreatment, which was even lower than the case without prechlorination. In addition, the algae removal efficiency increased with the elevation of $\mathrm{KMnO}_{4}$ and $\mathrm{Fe}(\mathrm{II})$ doses when the chlorine dose was fixed. Without chlorine preoxidation, the highest algae removal efficiency, i.e., $90 \%$, was obtained at the $\mathrm{KMnO}_{4}$ dose of $40 \mu \mathrm{M}$. Similar algae removal of $89 \%$ could be achieved after being preoxidized by $0.3 \mathrm{mg} / \mathrm{L}$ chlorine for the $\mathrm{KMnO}_{4}$ dose of $30 \mu \mathrm{M}$.

The increase of algae removal with elevation of chlorine dose from 0 to $0.5 \mathrm{mg} / \mathrm{L}$ can be explained by the low ratios of damaged cells found in Fig. 4, which indicated that chlorine at low doses mainly reacted with the organic matter, such as dissolved organics and S-AOM on the cells. The S-AOM proved to serve as a protective barrier can stabilize the algae cells, and decrease the algae removal efficiency (Fig. 2). The desorption of S-AOM from algae cells can benefit the algae removal (Clasen et al., 2000; Xie et al., 2013; Qi
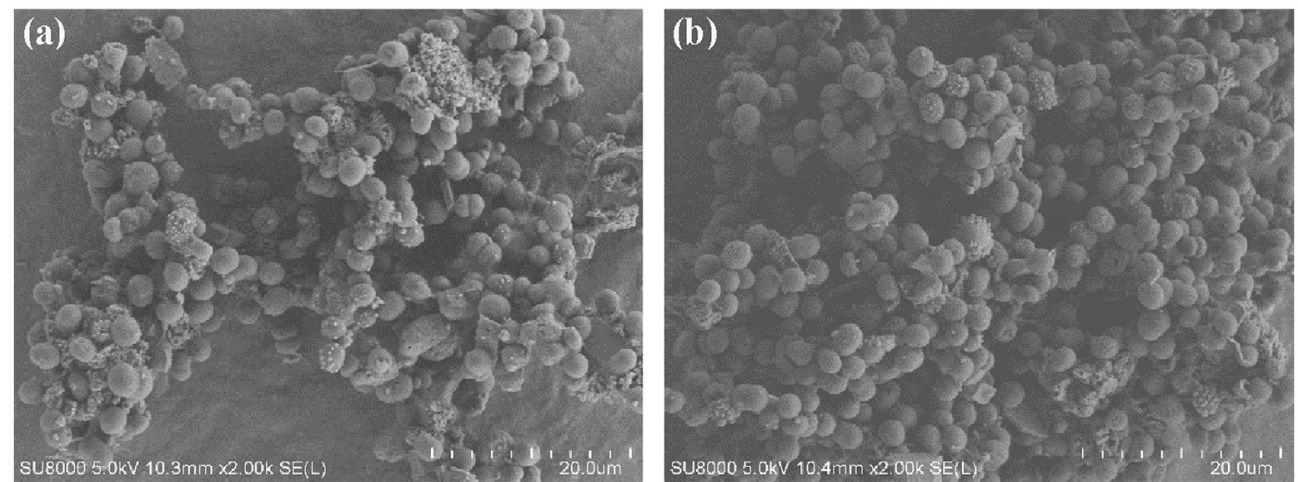

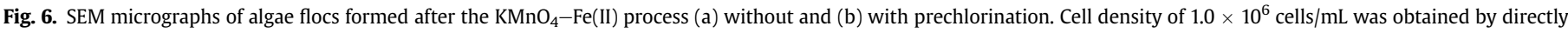
diluting with source water. Chlorine dose (if any) $=0.5 \mathrm{mg} / \mathrm{L}$. $\mathrm{RKMnO}_{4}: \mathrm{Fe}(\mathrm{II})=1: 3 ; \mathrm{KMnO}_{4}$ dose $=24 \mu \mathrm{M}$. 
et al., 2016a), and elevation of chlorine doses from 0 to $0.5 \mathrm{mg} / \mathrm{L}$ can lead to a more pronounced desorption effect. This result is consistent with a previous study showing that the low level of AOM in a water body induced by lower-dose chlorine oxidation mainly benefits coagulation (Bernhardt et al., 1985). In addition, the decrease in algae removal efficiency with further elevation of chlorine dose from 0.6 to $2 \mathrm{mg} / \mathrm{L}$ can be explained by the high level of IOM released from the large ratios of damaged cells found in Fig. 4, which has been reported to adversely influence algae removal (Garzon-Sanabria et al., 2013). A high level of IOM can decrease algae removal efficiency and increase the required coagulant dose by forming IOM-coagulant complexes (Pivokonsky et al., 2006).

Fig. 6 shows the SEM results for algae flocs formed after the $\mathrm{KMnO}_{4}-\mathrm{Fe}(\mathrm{II})$ process with and without prechlorination. As we can see from Fig. 6a, the algae cells were loosely bound by flocs formed in the $\mathrm{KMnO}_{4}-\mathrm{Fe}(\mathrm{II})$ process, and needed more surrounding flocs in order to be aggregated. With $0.5 \mathrm{mg} / \mathrm{L}$ chlorine preoxidation, the algae cells were easily captured by the flocs formed in the $\mathrm{KMnO}_{4}-\mathrm{Fe}$ (II) process, which benefited the floc aggregation for formation of tightly bounded algae flocs (Fig. 6b). This result can directly prove the positive function of moderate prechlorination in improving coagulation and aggregation. With moderate prechlorination, the S-AOM on the cells can be desorbed well without damaging the cell integrity, which finally benefits the algae removal by the $\mathrm{KMnO}_{4}-\mathrm{Fe}(\mathrm{II})$ process. A previous study (Xie et al., 2013) also reported that the improvement of algae removal by coagulation-sedimentation after preoxidation was likely due to the destruction of S-AOM on the cells. In addition, the algae cells still maintained their morphology after prechlorination compared with the original algae cells in Fig. S1. This result is consistent with the previous findings that chlorine can inactivate the algae cells and reduce the algae colloid stability without changing the cell morphology (Ma and Liu, 2002; Lin et al., 2009; Ma et al., 2012c).

\section{Conclusions}

This study directly proved that S-AOM could not only inhibit the algae removal by the $\mathrm{KMnO}_{4}-\mathrm{Fe}(\mathrm{II})$ process, but also protect the cell integrity from prechlorination damage. Moderate prechlorination can effectively eliminate the inhibitory role of S-AOM without damaging large ratios of cells, and finally promote the algae removal by the $\mathrm{KMnO}_{4}-\mathrm{Fe}(\mathrm{II})$ process. Chlorine doses of below $0.5 \mathrm{mg} / \mathrm{L}$ could achieve moderate prechlorination of directly diluted $M$. aeruginosa, and the ratios of damaged cells were below $4 \%$ after 5-min prechlorination. With moderate prechlorination, the problems of toxins release and DBPs formation at problematic level can be avoided. The algae removal of the $\mathrm{KMnO}_{4}-\mathrm{Fe}(\mathrm{II})$ process could be dramatically enhanced by the elevation of chlorine doses from 0 to $0.5 \mathrm{mg} / \mathrm{L}$ as more S-AOM was desorbed from algae cells during the 5-min preoxidation. In addition, moderate prechlorination could benefit the floc aggregation for formation of tightly bounded algae flocs, since the S-AOM-desorbed algae cells were easily captured by the flocs formed in the $\mathrm{KMnO}_{4}-\mathrm{Fe}(\mathrm{II})$ process. Thus, the implementation of moderate prechlorination may be practically applicable to enhance the algae removal in the $\mathrm{KMnO}_{4}-\mathrm{Fe}(\mathrm{II})$ process. It should be noted that all the findings were obtained with $M$. aeruginosa, and further verification is needed to extend the findings to other algal species.

\section{Acknowledgements}

This work was supported by the National Science Fund for Distinguished Young Scholars of China (Grant No. 51225805) and the National Natural Science Foundation of China (Grant No.
$51422813)$.

\section{Appendix A. Supplementary data}

Supplementary data related to this article can be found at http:// dx.doi.org/10.1016/j.watres.2016.09.042.

\section{References}

Bernhardt, H., Hoyer, O., Lusse, B., Schell, H., 1989. Influence of algogenic organicsubstances on flocculation and filtration. Acta Hydrochim. Hydrobiol. 17 (3), 235-277.

Bernhardt, H., Hoyer, O., Schell, H., Lusse, B., 1985. Reaction-mechanisms involved in the influence of algogenic organic-matter on flocculation. Z. Wasser Abwasser Forsch.-J. Water Wastewater Res. 18 (1), 18-30.

Chen, J.-J., Yeh, H.-H., 2005. The mechanisms of potassium permanganate on algae removal. Water Res. 39 (18), 4420-4428.

Clasen, J., Mischke, U., Drikas, M., Chow, C., 2000. An improved method for detecting electrophoretic mobility of algae during the destabilisation process of flocculation: flocculant demand of different species and the impact of DOC. J. Water Serv. Res. Technol.-Aqua 49 (2), 89-101.

Daly, R.I., Ho, L., Brookes, J.D., 2007. Effect of chlorination on Microcystis aeruginosa cell integrity and subsequent microcystin release and degradation. Environ. Sci. Technol. 41 (12), 4447-4453.

Fan, J.J., Rao, L., Chiu, Y.-T., Lin, T.-F., 2016. Impact of chlorine on the cell integrity and toxin release and degradation of colonial Microcystis. Water Res. 102, 394-404.

Fan, J.J., Ho, L., Hobson, P., Brookes, J., 2013. Evaluating the effectiveness of copper sulphate, chlorine, potassium permanganate, hydrogen peroxide and ozone on cyanobacterial cell integrity. Water Res. 47 (14), 5153-5164.

Fan, J.J., Hobson, P., Ho, L., Daly, R., Brookes, J., 2014. The effects of various control and water treatment processes on the membrane integrity and toxin fate of cyanobacteria. J. Hazard. Mater. 264, 313-322.

Feng, G.Z., Chu, H.Q., Dong, B.Z., 2014. Fouling effects of algogenic organic matters during nanofiltration of naproxen. Desalination 350, 69-78.

Gao, S.S., Du, M.A., Tian, J.Y., Yang, J.Y., Yang, J.X., Ma, F., Nan, J., 2010. Effects of chloride ions on electro-coagulation-flotation process with aluminum electrodes for algae removal. J. Hazard. Mater. 182 (1-3), 827-834.

Garzon-Sanabria, A.J., Ramirez-Caballero, S.S., Moss, F.E.P., Nikolov, Z.L., 2013. Effect of algogenic organic matter (AOM) and sodium chloride on Nannochloropsis salina flocculation efficiency. Bioresour. Technol. 143, 231-237.

Henderson, R.K., Parsons, S.A., Jefferson, B., 2008. The impact of algal properties and pre-oxidation on solid-liquid separation of algae. Water Res. 42 (8-9), 1827-1845.

Henderson, R.K., Parsons, S.A., Jefferson, B., 2010. The impact of differing cell and algogenic organic matter (AOM) characteristics on the coagulation and flotation of algae. Water Res. 44 (12), 3617-3624.

Kemp, A., John, J., 2006. Microcystins associated with Microcystis dominated blooms in the southwest wetlands, Western Australia. Environ. Toxicol. 21 (2), 125-130.

Li, P., Song, Y., Yu, S.L., 2014. Removal of Microcystis aeruginosa using hydrodynamic cavitation: performance and mechanisms. Water Res. 62, 241-248.

Lin, T.-F., Chang, D.-W., Lien, S.-K., Tseng, Y.-S., Chiu, Y.-T., Wang, Y.-S., 2009. Effect of chlorination on the cell integrity of two noxious cyanobacteria and their releases of odorants. J. Water Supply Res. Technol.-Aqua 58 (8), 539-551.

Ma, J., Liu, W., 2002. Effectiveness and mechanism of potassium ferrate(VI) preoxidation for algae removal by coagulation. Water Res. 36 (4), 871-878.

Ma, M., Liu, R.P., Liu, H.J., Qu, J.H., 2012a. Effect of moderate pre-oxidation on the removal of Microcystis aeruginosa by $\mathrm{KMnO}_{4}-\mathrm{Fe}(\mathrm{II})$ process: significance of the in-situ formed Fe(III). Water Res. 46 (1), 73-81.

Ma, M., Liu, R.P., Liu, H.J., Qu, J.H., 2012c. Chlorination of Microcystis aeruginosa suspension: cell lysis, toxin release and degradation. J. Hazard. Mater. 217, 279-285.

Ma, M., Liu, R.P., Liu, H.J., Qu, J.H., Jefferson, W., 2012b. Effects and mechanisms of pre-chlorination on Microcystis aeruginosa removal by alum coagulation: significance of the released intracellular organic matter. Sep. Purif. Technol. 86, $19-25$.

Pieterse, A., Cloot, A., 1997. Algal cells and coagulation, flocculation and sedimentation processes. Water Sci. Technol. 36 (4), 111-118.

Pivokonsky, M., Kloucek, O., Pivokonska, L., 2006. Evaluation of the production, composition and aluminum and iron complexation of algogenic organic matter. Water Res. 40 (16), 3045-3052.

Qi, J., Lan, H.C., Liu, R.P., Miao, S.Y., Liu, H.J., Qu, J.H., 2016b. Prechlorination of algaeladen water: the effects of transportation time on cell integrity, algal organic matter release, and chlorinated disinfection byproduct formation. Water Res. $102,221-228$

Qi, J., Lan, H.C., Miao, S.Y., Xu, Q., Liu, R.P., Liu, H.J., Qu, J.H., 2016a. KMnO $4-F e(I I)$ pretreatment to enhance Microcystis aeruginosa removal by aluminum coagulation: does it work after long distance transportation? Water Res. 88, 127-134.

Reynolds, C.S., 2007. Variability in the provision and function of mucilage in phytoplankton: facultative responses to the environment. Hydrobiologia 578 (1), 37-45.

Rippka, R., Deruelles, J., Waterbury, J.B., Herdman, M., Stanier, R.Y., 1979. Generic 
assignments, strain histories and properties of pure cultures of cyanobacteria. J. General Microbiol. 111, 1-61. MAR.

Sano, D., Ishifuji, S., Sato, Y., Imae, Y., Takaara, T., Masago, Y., Omura, T., 2011. Identification and characterization of coagulation inhibitor proteins derived from cyanobacterium Microcystis aeruginosa. Chemosphere 82 (8), 1096-1102.

Shen, H., Song, L.R., 2007. Comparative studies on physiological responses to phosphorus in two phenotypes of bloom-forming microcystis. Hydrobiologia 592, 475-486.

Shen, Q.H., Zhu, J.W., Cheng, L.H., Zhang, J.H., Zhang, Z., Xu, X.H., 2011. Enhanced algae removal by drinking water treatment of chlorination coupled with coagulation. Desalination 271 (1-3), 236-240.

Sun, L.H., Liu, R.P., Xia, S.J., Yang, Y.L., Li, G.B., 2009. Enhanced As(III) removal with permanganate oxidation, ferric chloride precipitation and sand filtration as pretreatment of ultrafiltration. Desalination 243 (1-3), 122-131.

Takaara, T., Sano, D., Masago, Y., Omura, T., 2010. Surface-retained organic matter of Microcystis aeruginosa inhibiting coagulation with polyaluminum chloride in drinking water treatment. Water Res. 44 (13), 3781-3786.

Wert, E.C., Dong, M.M., Rosario-Ortiz, F.L., 2013. Using digital flow cytometry to assess the degradation of three cyanobacteria species after oxidation processes. Water Res. 47 (11), 3752-3761.

Wu, Z.X., Gan, N.Q., Huang, Q., Song, L.R., 2007. Response of Microcystis to copper stress - do phenotypes of Microcystis make a difference in stress tolerance? Environ. Pollut. 147 (2), 324-330.

Xie, P.C., Ma, J., Fang, J.Y., Guan, Y.H., Yue, S.Y., Li, X.C., Chen, L.W., 2013. Comparison of permanganate preoxidation and preozonation on algae containing water: cell integrity, characteristics, and chlorinated disinfection byproduct formation. Environ. Sci. Technol. 47 (24), 14051-14061.

Yang, Y.X., Chen, J., 2013. Advanced treatment of drinking water by ultrafiltration membrane. Adv. Mater. Res. 647, 543-547.

Zhou, S.Q., Zhu, S.M., Shao, Y.S., Gao, N.Y., 2015. Characteristics of C-, N-DBPs formation from algal organic matter: role of molecular weight fractions and impacts of pre-ozonation. Water Res. 72, 381-390.

Zhu, M.Q., Gao, N.Y., Chu, W.H., Zhou, S.Q., Zhang, Z.D., Xu, Y.Q., Dai, Q., 2015. Impact of pre-ozonation on disinfection by-product formation and speciation from chlor(am)ination of algal organic matter of Microcystis aeruginosa. Ecotoxicol. Environ. Saf. 120, 256-262. 